\title{
Mineralization and herbage recovery of animal manure nitrogen after application to various soil types
}

\author{
G. M. Shah • M. I. Rashid • G. A. Shah • \\ J. C. J. Groot • E. A. Lantinga
}

Received: 2 February 2012 / Accepted: 25 June 2012 / Published online: 22 July 2012

(C) The Author(s) 2012. This article is published with open access at Springerlink.com

\begin{abstract}
Background and aim Typical values of plant available nitrogen $(\mathrm{N})$ from animal manures are provided in fertilizer recommendation schemes. However, only a few attempts have been made thus far to study the variation in these values among contrasting soil types. The objective of this study was to examine the interactions between animal manure and soil types on $\mathrm{N}$ mineralization and total plant $\mathrm{N}$ recovery (shoots + roots) during one growing season.

Methods A pot experiment was conducted in a greenhouse during a growth period of 180 days. Experimental treatments included solid cattle manure (SCM), cattle slurry (CS) and poultry manure (PM), all applied to sandy, clay and peat soils sown with perennial ryegrass. Total $\mathrm{N}$ application rate was $120 \mathrm{~kg} \mathrm{ha}^{-1}$.

Results There were clear interactions $(P<0.05)$ between the manure and soil types on $\mathrm{N}$ mineralization and total plant $\mathrm{N}$ recovery. For each manure type, both parameters followed the pattern $(P<0.01)$ : peat $>$ sandy $>$ clay. In case of the peat soil, net mineralization of the applied organic N was on average $90 \%$ from PM, $39 \%$ from SCM and $26 \%$ from CS. However, in the clay soil a
\end{abstract}

Responsible Editor: Hans Lambers.

G. M. Shah $(\bowtie) \cdot$ M. I. Rashid · G. A. Shah •

J. C. J. Groot • E. A. Lantinga

Organic Farming Systems Group, Wageningen University, P.O. Box 563, 6700 AN Wageningen, The Netherlands e-mail: ghulamm.shah@wur.nl positive net $\mathrm{N}$ mineralization occurred only from $\mathrm{PM}$ (42\%). Besides, significant proportions of the applied mineral $\mathrm{N}$ from SCM (17\%) and CS (35\%) were immobilized in this soil type. Consequently, apparent total plant $\mathrm{N}$ recovery was highest in the peat soil with values of 80,57 and $50 \%$ from PM, CS and SCM, respectively. In contrast, these values were only 57,28 and $15 \%$ for the clay soil.

Conclusions It is concluded that wide variations do exist in the extent of net $\mathrm{N}$ mineralization and plant $\mathrm{N}$ recovery from a given animal manure type when applied to diverging soil types. This indicates the need for more soil-specific manure fertilizer recommendations.

Keywords Solid cattle manure $\cdot$ Cattle slurry $\cdot$ Poultry manure $\cdot$ Soil type $\cdot$ Mineralization $\cdot$ Nitrogen utilization $\cdot$ Fertilizer recommendations

\section{Introduction}

Typical values of plant available nitrogen $(\mathrm{N})$ from animal manures during one growing season are provided in handbooks for farmers. According to MAFF (1979) and Brockman (1988) these are $25 \%$ of the $\mathrm{N}_{\text {total }}$ from solid cattle manure, $50 \%$ from cattle slurry and $60 \%$ from poultry manure in the year of their application. However, in reality these values may vary widely after addition of the same manure source to contrasting soil types (Castellanos and Pratt 1981; Chae and Tabatabai 1986; Sørensen and Jensen 1995a and b). 
After soil application, part of the ammonium-N $\left(\mathrm{NH}_{4}{ }^{+}-\mathrm{N}\right)$ from manure is immobilized by microbes, fixed by clay and/or adsorbed on negatively charged surfaces. This immobilized and retained $\mathrm{N}$ as well as the organic $\mathrm{N}$ fraction of applied manure has to be first mineralized or desorbed before it is available for plant uptake. All these $\mathrm{N}$ transformations are rather complex and controlled by a number of soil factors i.e. soil texture (Sørensen and Jensen 1995a), soil characteristics (Schjonning et al. 1999), microbial activity (Bengtsson et al. 2002) and environmental factors (Katterer et al. 1998; Watts et al. 2007). It has been shown in earlier studies that the net $\mathrm{N}$ mineralization rate of manure is negatively correlated with the soil clay content (Castellanos and Pratt 1981; Chescheir et al. 1986; Sørensen and Jensen 1995a and b). The three main reasons for this phenomenon are (i) fixation of $\mathrm{NH}_{4}{ }^{+}-\mathrm{N}$ into the interlayer spaces of clay minerals (Nieder et al. 2011), (ii) entrapment of organic $\mathrm{N}$ compounds in soil aggregates inaccessible to microbes and (iii) physical protection of the microbial biomass in the soil structure (Van Veen and Kuikman 1990). According to Magdoff (1978), N mineralization from added organic materials can also be affected by the rate of mineralization of native soil organic matter $(\mathrm{OM})$. It is well-known that agronomic practices that build-up soil OM greatly improve soil fertility and thereby the potential for $\mathrm{N}$ mineralization (Wood and Edwards 1992; Liu et al. 2006). It is therefore expected that soil types varying in all of these characteristics will have diverging consequences for the net availability of animal manure $\mathrm{N}$ to crops.

Several attempts have been made to examine the effects of soil physical and chemical characteristics on manure $\mathrm{N}$ mineralization, but nearly all of this work has been carried out in the absence of plants (Castellanos and Pratt 1981; Chescheir et al. 1986; Sørensen and Jensen 1995a and b; Thomsen and Olesen 2000). Jonasson et al. (2006) demonstrated that measurements of net $\mathrm{N}$ mineralization in a cropless soil yield underestimations of plant $\mathrm{N}$ availability. Growing plants are known to enhance the rate of $\mathrm{N}$ turnover in the rhizosphere (Jonasson et al. 2006) since root excretions of energy sources stimulate the soil microbial biomass and its activity (Bais et al. 2006). In addition, competition between roots and micro-organisms for $\mathrm{N}$ may also affect net $\mathrm{N}$ mineralization (Hodge et al. 2000). Therefore, estimation of the influences that cropped soils could have on $\mathrm{N}$ mineralization and overall plant
$\mathrm{N}$ recovery from amended manure is essential for more effective use of fertilizer resources. The aim of the current work thus was to study the interactions between three animal manure (solid cattle manure, cattle slurry and poultry manure) and soil types (sandy, clay and peat) on $\mathrm{N}$ mineralization and plant $\mathrm{N}$ recovery during one growing season with perennial ryegrass (Lolium perenne L.) as test crop.

\section{Materials and methods}

To pursue the objective outlined above, a pot experiment was carried out for 180 days under controlled environmental conditions in a greenhouse of Wageningen University and Research Centre, the Netherlands (latitude $55^{\circ} 99^{\prime} \mathrm{N}$ and longitude $5^{\circ} 66^{\prime} \mathrm{E}$ ). In order to focus only on the main research question we have carried out this experiment under glasshouse conditions and not outdoors to avoid disturbing effects of changing weather conditions.

Soils and manures: collection and characteristics

Sandy, clay and peat soils from different regions of the Netherlands were used in this explorative study. All these soils were collected from a depth of $0-30 \mathrm{~cm}$. After collection from the field, representative samples were taken to determine soil texture and contents of organic matter (OM), total carbon (C), total $\mathrm{N}, \mathrm{NH}_{4}{ }^{+}$$\mathrm{N}$, nitrate- $\mathrm{N}\left(\mathrm{NO}_{3}{ }^{-}-\mathrm{N}\right)$, total phosphorus $(\mathrm{P})$, total potassium $(\mathrm{K})$, magnesium $(\mathrm{Mg})$, sodium $(\mathrm{Na}), \mathrm{CEC}$ and $\mathrm{pH}$ (Table 1). Soil texture was measured using laser diffractometry (Coulter LS 230, Beckman Coulter, USA) as described by Buurman et al. (2001). The soil OM content was determined after drying the samples at $105^{\circ} \mathrm{C}$ for $24 \mathrm{~h}$ and subsequent ignition of the dried samples at $525^{\circ} \mathrm{C}$ for $6 \mathrm{~h}$. Total $\mathrm{N}$ was measured after Kjeldahl digestion (MAFF 1986). The $\mathrm{NH}_{4}{ }^{+}-\mathrm{N}$ and $\mathrm{NO}_{3}{ }^{-}-\mathrm{N}$ contents were measured using a 1:10 soil/0.01 $\mathrm{M} \mathrm{CaCl}_{2}$ extract by means of segment-flow analysis (Houba et al. 1989) and this extract was also used for determining the soil $\mathrm{pH}$ using a pH meter (inoLab pH meter level 1, WTW GmbH \& Co. KG, Germany). Total CEC, C, P, K, Mg and $\mathrm{Na}$ were determined according to the procedures described by Houba et al. (1989).

Three animal manures were applied to each soil type: solid cattle manure (SCM), cattle slurry (CS) 
Table 1 Physical and chemical properties of the soils

\begin{tabular}{|c|c|c|c|c|c|c|c|c|c|c|c|c|c|c|}
\hline \multirow[t]{2}{*}{ Soil } & \multirow{2}{*}{$\begin{array}{l}\mathrm{OM} \\
(\%)\end{array}$} & \multicolumn{3}{|l|}{ Texture $^{\mathrm{a}}(\%)$} & \multirow{2}{*}{$\frac{\mathrm{N}_{\text {total }}}{(\mathrm{mg} \mathrm{kg}}$} & $\mathrm{NH}_{4}-\mathrm{N}$ & \multirow[t]{2}{*}{$\mathrm{NO}_{3}-\mathrm{N}$} & \multirow[t]{2}{*}{$\mathrm{P}_{\text {total }}$} & \multirow[t]{2}{*}{$\mathrm{K}_{\text {total }}$} & \multirow[t]{2}{*}{$\mathrm{Mg}$} & \multirow[t]{2}{*}{$\mathrm{Na}$} & \multirow{2}{*}{$\begin{array}{l}\text { CEC } \\
- \\
\left(\mathrm{cmol} \mathrm{kg}^{-1}\right)\end{array}$} & \multirow[t]{2}{*}{$\mathrm{C} / \mathrm{N}$} & \multirow[t]{2}{*}{$\mathrm{pH}$} \\
\hline & & $20-2000(\mu \mathrm{m})$ & $2-20(\mu \mathrm{m})$ & $<2(\mu \mathrm{m})$ & & $-1)$ & & & & & & & & \\
\hline Sandy & 2.4 & 86 & 10 & 4 & 1016 & 2.5 & 13.0 & 3.6 & 17 & 120 & 7 & 3.3 & 14 & 5.7 \\
\hline Clay & 2.8 & 9 & 57 & 34 & 1440 & 1.6 & 13.3 & 1.1 & 37 & 102 & 12 & 19.3 & 10 & 7.4 \\
\hline Peat & 31.6 & 32 & 48 & 20 & 11896 & 7.5 & 72.9 & 1.3 & 335 & 381 & 78 & 41.8 & 13 & 4.7 \\
\hline
\end{tabular}

a $<2 \mu \mathrm{m}$ (clay), 2-20 $\mu \mathrm{m}$ (silt) and 20-2000 $\mu \mathrm{m}$ (sand)

and poultry manure (PM). The SCM was collected from a tying stall barn where cereal straw (wheat and barley mixture) was used as bedding material at a daily rate of $5 \mathrm{~kg}$ per livestock unit (i.e. $500 \mathrm{~kg}$ live weight). The CS was taken from a cubicle barn where urine and faeces were collected underneath a slatted floor while the PM produced by broilers consisted of bedding material (chopped straw) and a mixture of excreta. All the manures were applied directly from barns to the soils without intermediate storage. Before application, manures were sampled and analysed for contents of total $\mathrm{C}$, total $\mathrm{N}$, mineral $\mathrm{N}\left(\mathrm{NH}_{4}{ }^{+}-\mathrm{N}+\mathrm{NO}_{3}{ }^{-}-\mathrm{N}\right)$, dry matter (DM) and OM (Table 2). Total $\mathrm{C}$ was determined following digestion with dichromate (MAFF 1986). Total $\mathrm{N}$ was measured after Kjeldahl digestion (MAFF 1986). Mineral $\mathrm{N}$ was measured in a 1:10 manure/0.01 $\mathrm{M} \mathrm{CaCl}_{2}$ extract by means of segmentflow analysis (Houba et al. 1989). The DM content was determined after drying the samples at $105^{\circ} \mathrm{C}$ for 24 h. Subsequently, OM content was determined gravimetrically through ignition of the dried samples at $525{ }^{\circ} \mathrm{C}$ for $6 \mathrm{~h}$ (Anonymous 1998).

Experimental setup and treatments

All the soils were sieved using a $4 \mathrm{~mm}$ mesh frame in order to remove plant roots and other debris. Thereafter, plastic pots were filled with the three soils; amounts were ranging from $9-15 \mathrm{~kg}$ per pot depending on their bulk densities. Each pot (height $30 \mathrm{~cm}$, surface area $0.071 \mathrm{~m}^{2}$ ) with four holes in the bottom was kept on a plastic plate in order to collect and recycle leachate if any. Subsequently, the manures were applied to the soils at an application rate of $120 \mathrm{~kg} \mathrm{~N}^{-1}$ and manually incorporated in the top $10 \mathrm{~cm}$ in order to avoid ammonia emission (Webb et al. 2010). In addition, a control of each soil type was included with similar soil preparation, but without manure addition. The treatments were arranged in a randomized complete block design with three replicates.

Two days after manure application, perennial ryegrass was sown in all of the pots at a seed rate of $0.3 \mathrm{~g}$ $\operatorname{pot}^{-1}$. The environmental conditions were controlled to provide $16 \mathrm{~h}$ of daylight and $8 \mathrm{~h}$ darkness with temperatures of $18{ }^{\circ} \mathrm{C}$ and $12{ }^{\circ} \mathrm{C}$, respectively. The soil moisture content was maintained at ca. $60 \%$ water holding capacity (WHC) throughout the experimental period in order to avoid denitrification losses (Mosier et al. 2002). For this purpose, water was applied daily using a hand sprinkler with extreme care whilst following the increase in WHC with a low-cost moisture meter (FY-901, Hangzhou FCJ I\&E Co., Ltd, China).

Soil sampling and analysis

At the end of the experiment, soil samples were collected to estimate the contents of residual mineral $\mathrm{N}\left(\mathrm{NH}_{4}{ }^{+}-\mathrm{N}+\right.$ $\mathrm{NO}_{3}{ }^{-}-\mathrm{N}$ ) and $\mathrm{pH}$ in all treatments. For this purpose, three
Table 2 Chemical characteristics of the manures

${ }^{\text {a }}$ Sum of $\mathrm{NH}_{4}{ }^{+}-\mathrm{N}$ and $\mathrm{NO}_{3}{ }^{-} \mathrm{N}$

${ }^{a}$ Sum of $\mathrm{NH}_{4}{ }^{+}-\mathrm{N}$ and $\mathrm{NO}_{3}{ }^{-}-\mathrm{N}$

\begin{tabular}{|c|c|c|c|c|c|c|}
\hline \multirow[t]{2}{*}{ Manure } & \multirow[t]{2}{*}{ DM $(\%)$} & \multirow[t]{2}{*}{ OM (\%) } & $\mathrm{N}_{\text {total }}$ & ${ }^{\mathrm{a}} \mathrm{N}_{\text {mineral }}$ & $\mathrm{N}_{\text {organic }}$ & \multirow[t]{2}{*}{$\mathrm{C} / \mathrm{N}$} \\
\hline & & & \multicolumn{3}{|c|}{$\left(\mathrm{g} \mathrm{kg}^{-1}\right.$ of $\left.\mathrm{DM}\right)$} & \\
\hline Solid cattle manure & 19.7 & 14.1 & 32.5 & 6.3 & 26.2 & 10 \\
\hline Cattle slurry & 10.0 & 7.2 & 38.9 & 17.0 & 22.0 & 8 \\
\hline Poultry manure (broiler) & 41.6 & 25.8 & 37.7 & 10.1 & 27.6 & 7 \\
\hline
\end{tabular}


random samples were taken from each pot with a soil auger $(\sim 1.5 \mathrm{~cm}$ diameter) from top to bottom. After sampling, soils were dried in an oven at $40{ }^{\circ} \mathrm{C}$ for $48 \mathrm{~h}$ and ground to pass a $1 \mathrm{~mm}$ sieve. Thereafter, all the samples were analysed for mineral $\mathrm{N}$ using a 1:10 soil/ $0.01 \mathrm{M} \mathrm{CaCl}_{2}$ extract by means of segment-flow analysis (Houba et al. 1989). Soil $\mathrm{pH}$ was measured from the same extract using a $\mathrm{pH}$ meter.

Plant harvesting

\section{Shoot harvesting}

During the entire experimental period of 6 months, the grass plants were harvested three times: 60, 120 and 180 days after sowing. During the 1 st and 2 nd harvest, plants were clipped with a scissor $4 \mathrm{~cm}$ above soil level, whereas during the $3 \mathrm{rd}$ harvest they were cut at ground level. Each time, fresh shoot biomass from the pots was measured and representative samples were oven-dried at $70{ }^{\circ} \mathrm{C}$ for $48 \mathrm{~h}$ (Sharkey 1970), weighed, ground to pass a $1 \mathrm{~mm}$ sieve and analysed for total $\mathrm{N}$ content after Kjeldahl digestion as described by Houba et al. (1989). Finally, shoot $\mathrm{N}$ uptake from each pot was calculated by multiplying the shoot DM yield with its $\mathrm{N}$ content.

\section{Root harvesting}

At the final harvest, roots of the grass were separated from soil in each pot in order to estimate total DM yield and $\mathrm{N}$ uptake. For this purpose, the whole soil clump from a pot was taken out and placed in a container filled with cold water. After $2 \mathrm{~h}$ of soaking, the clump was manually divided into $6-8$ pieces. These were taken out of the container one by one and placed on a $0.5 \mathrm{~mm}$ mesh frame to separate roots from soil with a jet of tap water. In addition, the remaining roots were recovered by decanting the soil-water mixture through a sieve with the same mesh size. After separation from the soil, the root material was dried in an oven at $70{ }^{\circ} \mathrm{C}$ for $48 \mathrm{~h}$ (Sharkey 1970), weighed, ground to pass a $1 \mathrm{~mm}$ sieve and analysed for total $\mathrm{N}$ content through Kjeldahl digestion (Houba et al. 1989). Subsequently, root $N$ yield of each pot was calculated by multiplying the root DM yield with its $\mathrm{N}$ content. Together with the final amount of soil mineral $\mathrm{N}$, this enabled us to construct an $\mathrm{N}$ balance in order to calculate the fraction of net mineralized organic manure $\mathrm{N}$ as described by Yang et al. (2004).
Plant $\mathrm{N}$ recovery calculations

At the end of the experiment, shoot $\mathrm{N}$ uptake from each harvest as well as root $\mathrm{N}$ uptake at final harvest were summed to calculate total $\mathrm{N}$ uptake by the grass from each treatment. Subsequently, total N recovery (TNR) was calculated as:

$\operatorname{TNR}(\%)=100 * \frac{\left(T N U_{\text {manured }}\right)-\left(T N U_{\text {control }}\right)}{T N_{\text {applied }}}$

Where $\mathrm{TNU}_{\text {manured }}$ is total $\mathrm{N}$ uptake $\left(\mathrm{g} \mathrm{m}^{-2}\right)$ by the grass from manured pots, $\mathrm{TNU}_{\text {control }}$ is total $\mathrm{N}$ uptake $\left(\mathrm{g} \mathrm{m}^{-2}\right)$ by the grass from unfertilized pots and $\mathrm{TN}_{\text {applied }}$ is total $\mathrm{N}$ applied $\left(\mathrm{g} \mathrm{m}^{-2}\right)$ with manure.

\section{Statistical analysis}

Statistical analysis was carried out by analysis of variance using Genstat (13 ${ }^{\text {th }}$ Edition, VSN International, Hemel Hempstead, UK). Effects of manure type, soil type and their interactions on $\mathrm{N}$ mineralization, and the different DM yield and $\mathrm{N}$ uptake parameters were tested. For each variable, if the overall effect was significant, differences among the treatments were further compared using Tukey's test at $5 \%$ probability level.

\section{Results}

Average crop $\mathrm{N}$ uptakes from all treatments are presented in Table 3. Total uptake of $\mathrm{N}$ (shoots + roots) by the grass from unfertilized soils was highest $(P<0.05)$ from peat soil (Table 3 ), whereas there was no difference $(P>0.05)$ between the sandy and clay soil (Table 3). Over the 180 days growth period, total $\mathrm{N}$ uptake followed the pattern $(P<0.001)$ : $\mathrm{PM}>\mathrm{CS}>$ $\mathrm{SCM}$ in each soil type. From each manure, TNR by the grass grown in the peat soil was higher $(P<0.001)$ compared to the sandy or clay soil. There were clear interactions $(P<0.05)$ between the different manure and soil types (Fig. 1). On average, $80 \%$ of the total $\mathrm{N}$ applied was recovered from PM, $57 \%$ from CS and $50 \%$ from SCM in the peat soil (Fig. 1). In contrast, the respective values were only 57,28 and $15 \%$ for the clay soil. The TNR from both SCM and CS was lower in the clay than in the sandy soil $(P<0.05)$, but for PM there was no difference between these soil 
Table 3 DM yield and N uptake by perennial ryegrass after 180 days of growth period

\begin{tabular}{|c|c|c|c|c|c|c|c|c|c|c|}
\hline & \multicolumn{3}{|c|}{ DM yield $\left(\mathrm{g} \mathrm{m}^{-2}\right)$} & \multirow{2}{*}{$\begin{array}{l}\mathrm{DM}_{\text {root }} \\
(\% \text { of total DM) }\end{array}$} & \multicolumn{3}{|c|}{$\mathrm{N}$ uptake $\left(\mathrm{g} \mathrm{m}^{-2}\right)$} & \multirow{2}{*}{$\begin{array}{l}\mathrm{N}_{\text {root }}(\% \text { of } \\
\text { total uptake })\end{array}$} & \multirow[t]{2}{*}{$N_{U E}^{a}$} & \multirow{2}{*}{$\begin{array}{l}\mathrm{pH} \\
\mathrm{CaCl}_{2}\end{array}$} \\
\hline & Roots & Shoots & Total & & Roots & Shoots & Total & & & \\
\hline \multicolumn{11}{|l|}{ Sandy } \\
\hline Control & $187 \mathrm{de}$ & $394 \mathrm{gh}$ & $581 \mathrm{ef}$ & 32 & $1.4 \mathrm{~cd}$ & $5.2 \mathrm{fgh}$ & $6.6 \mathrm{gh}$ & 21 & 88 & 6.02 \\
\hline SCM & $277 \mathrm{ab}$ & 532 def & 809 bc & 34 & $2.5 \mathrm{a}$ & $6.9 \mathrm{f}$ & $9.4 \mathrm{f}$ & 27 & 86 & 6.08 \\
\hline PM & $295 \mathrm{ab}$ & $726 \mathrm{ab}$ & $1021 \mathrm{a}$ & 29 & $1.9 \mathrm{bc}$ & $12.0 \mathrm{~d}$ & $13.9 \mathrm{~d}$ & 14 & 74 & 6.09 \\
\hline $\mathrm{CS}$ & $322 \mathrm{a}$ & $672 a b c$ & $994 \mathrm{a}$ & 32 & $2.3 \mathrm{ab}$ & $9.5 \mathrm{e}$ & $11.8 \mathrm{e}$ & 20 & 84 & 6.01 \\
\hline \multicolumn{11}{|l|}{ Clay } \\
\hline Control & 145 ef & $330 \mathrm{~h}$ & $475 \mathrm{f}$ & 31 & $1.1 \mathrm{e}$ & $3.8 \mathrm{~h}$ & $4.8 \mathrm{~h}$ & 22 & 99 & 7.62 \\
\hline $\mathrm{SCM}$ & $211 \mathrm{~cd}$ & $420 \mathrm{fgh}$ & $631 \mathrm{e}$ & 33 & $1.7 \mathrm{~cd}$ & $4.9 \mathrm{gh}$ & $6.6 \mathrm{gh}$ & 25 & 96 & 7.62 \\
\hline $\mathrm{PM}$ & $220 \mathrm{~cd}$ & $645 \mathrm{bcd}$ & $865 \mathrm{bc}$ & 25 & $1.5 \mathrm{~cd}$ & $10.1 \mathrm{e}$ & $11.6 \mathrm{e}$ & 13 & 75 & 7.54 \\
\hline $\mathrm{CS}$ & $263 \mathrm{bc}$ & 507 efg & $770 \mathrm{~cd}$ & 34 & $1.9 \mathrm{abc}$ & $6.3 \mathrm{fg}$ & $8.2 \mathrm{fg}$ & 23 & 94 & 7.55 \\
\hline \multicolumn{11}{|l|}{ Peat } \\
\hline Control & $88 \mathrm{f}$ & 569 cde & $657 \mathrm{de}$ & 13 & $1.1 \mathrm{~d}$ & $16.2 \mathrm{c}$ & $17.3 \mathrm{c}$ & 6 & 38 & 4.77 \\
\hline SCM & $98 \mathrm{fg}$ & $740 \mathrm{ab}$ & $838 \mathrm{bc}$ & 12 & $1.4 \mathrm{~cd}$ & $21.9 \mathrm{~b}$ & $23.3 \mathrm{~b}$ & 6 & 36 & 4.70 \\
\hline PM & $112 \mathrm{fg}$ & $787 \mathrm{a}$ & $899 a b$ & 12 & $1.7 \mathrm{~cd}$ & $25.2 \mathrm{a}$ & $26.9 \mathrm{a}$ & 6 & 33 & 4.92 \\
\hline $\mathrm{CS}$ & $123 \mathrm{fg}$ & $781 \mathrm{a}$ & $904 \mathrm{ab}$ & 14 & $1.8 \mathrm{bc}$ & $22.3 \mathrm{~b}$ & $24.1 \mathrm{~b}$ & 8 & 38 & 4.86 \\
\hline \multicolumn{11}{|c|}{ Statistical analysis (P-values) } \\
\hline $\mathrm{MT}^{\mathrm{c}}$ & $<0.001$ & $<0.001$ & $<0.001$ & nd & $<0.001$ & $<0.001$ & $<0.001$ & nd & $<0.001$ & 0.711 \\
\hline$S T^{d}$ & $<0.001$ & $<0.001$ & $<0.001$ & nd & $<0.001$ & $<0.001$ & $<0.001$ & nd & $<0.001$ & $<0.001$ \\
\hline $\mathrm{MT} \times \mathrm{ST}$ & 0.001 & 0.018 & 0.003 & nd & 0.033 & $<0.001$ & $<0.001$ & nd & 0.189 & 0.205 \\
\hline
\end{tabular}

${ }^{\mathrm{a}}$ Nitrogen use efficiency (kg DM production per $\mathrm{kg} \mathrm{N}$ uptake)

${ }^{\mathrm{c}}$ Manure type, ${ }^{\mathrm{d}}$ Soil type, $n d$ Not determined

*Values followed by different letters within a column are significantly different $(P<0.05)$ from each other

types (Fig. 1). Of the TNR from all treatments, the highest contribution came from the $1^{\text {st }}$ grass harvest, and the amount of recovered $\mathrm{N}$ gradually decreased in the two subsequent harvests (data not shown).

The distribution between shoots and roots of $\mathrm{N}$ taken up by the grass differed greatly among the soil and manure types. On average, a relatively high proportion of the total $\mathrm{N}$ uptake ended up in the roots of grass grown in the sandy and clay soils $(\sim 21 \%)$ compared to only about $7 \%$ in the peat treatments (Table 3). Visual observations revealed that the roots in peat soil were concentrated in the top $10 \mathrm{~cm}$ of soil, whereas these were distributed throughout the whole soil profile in case of the sandy and clay pots. In the latter two soil types, the tendency for investment of $\mathrm{N}$ in the roots differed among the manure types in the order: SCM $>C S>P M$ (Table 3 ). However, in the peat soil no differences were observed (Table 3).
Calculation of the net $\mathrm{N}$ balance over 180 days revealed the interactions $(P<0.05)$ between the manure and soil types on net $\mathrm{N}$ recovery of organic $\mathrm{N}$ (Table 4). This net $\mathrm{N}$ recovery was due to the net

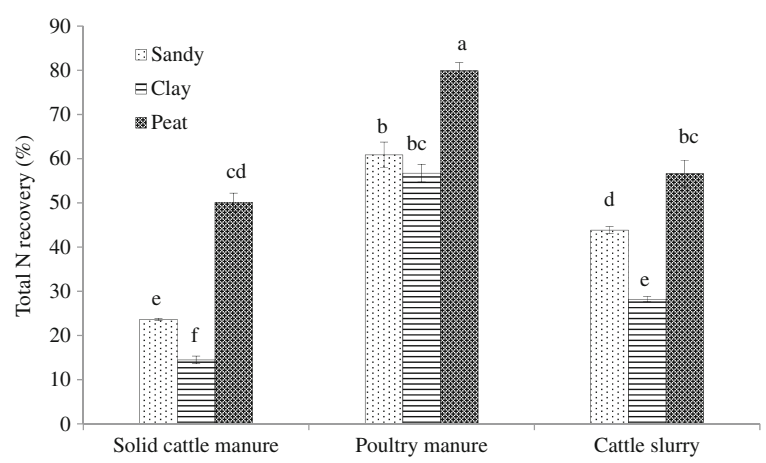

Fig. 1 Net recovery of total manure $\mathrm{N}$ by perennial ryegrass (shoots + roots) over a period of 180 days. Error bars represent standard error $( \pm)$ of the mean. Bars with different letters are different from each other at $5 \%$ probability level 
mineralization in the treatments. Overall, $\mathrm{N}$ mineralization from all manures was highest in the peat soil $(P<$ $0.001)$. Net mineralization of organic $\mathrm{N}$ from $\mathrm{SCM}$ and CS occurred only in the sandy soil (7.6 and $2.9 \%$ of the initial $\mathrm{N}_{\text {organic }}$, respectively) and the peat soil (38.5 and $26.2 \%$, respectively) (Table 4). In contrast, part of the mineral $\mathrm{N}$ from SCM ( $\sim 4 \%$ of the initial $\left.\mathrm{N}_{\text {organic }}\right)$ and CS $(\sim 27 \%)$ was net immobilized in the clay soil. On the other hand, PM showed net mineralization (42-90\% of initial organic $\mathrm{N}$ ) in all of the soils (Table 4).

Total DM production per $\mathrm{kg} \mathrm{N}$ uptake was significantly influenced by the soil types (Fig. 2a and Table 3). At the same level of $\mathrm{N}$ uptake, the total DM yield of shoots and roots together was much lower for the peat soil than for the sandy or clay soils (Figs. $2 \mathrm{~b}$ and c). N uptake in grass shoots on peat soil was much higher than for the other soil types (Table 3), but the shoot DM yield was not increased proportionally (Fig. 2b). As a result, the $\mathrm{N}$ content of the grass was $\sim 2.5$ times higher in the peat treatments compared to the others, indicating luxury $\mathrm{N}$ consumption. The number of grass tillers in the peat soil at final harvest was only about half of that in the other soils (data not shown). Although no data were collected, the leaves of the grass plants produced on peat soil were much wider and longer relative to those produced on the other two soils throughout the experiment.

\section{Discussion}

The effects of soil type on total $\mathrm{N}$ uptake, TNR and net $\mathrm{N}$ mineralization from the applied manures

Table $4 \mathrm{~N}$ balance in the pots based on the $\mathrm{N}$ addition with manure, total $\mathrm{N}$ uptake (shoots + roots) by perennial ryegrass and residual mineral $\mathrm{N}$ in the soils over a period of 180 days

\begin{tabular}{|c|c|c|c|c|c|c|c|c|c|}
\hline & \multicolumn{3}{|c|}{$\mathrm{N}$ applied } & \multicolumn{2}{|c|}{$\mathrm{N}$ uptake by grass } & \multicolumn{2}{|c|}{ Final mineral $\mathrm{N}$ in soil } & \multicolumn{2}{|c|}{ Net recovery of organic manure $\mathrm{N}$} \\
\hline & Total & Mineral & Organic & Total & From manure & Total & From manure & $\mathrm{A}^{\mathrm{a}}$ & $\mathrm{B}^{\mathrm{b}}$ \\
\hline & \multicolumn{3}{|c|}{$\left(\mathrm{g} \mathrm{m}^{-2}\right)$} & \multicolumn{2}{|l|}{$\left(\mathrm{g} \mathrm{m}^{-2}\right)$} & \multicolumn{2}{|l|}{$\left(\mathrm{g} \mathrm{m}^{-2}\right)$} & $\left(\mathrm{g} \mathrm{m}^{-2}\right)$ & $(\%)$ \\
\hline \multicolumn{10}{|l|}{ Sandy } \\
\hline Control & 0 & & & 6.6 & & 0.86 & & & \\
\hline $\mathrm{SCM}$ & 12 & 2.3 & 9.7 & 9.4 & 2.8 & 1.10 & 0.24 & $0.74 \mathrm{~cd}$ & $7.6 \mathrm{~d}$ \\
\hline PM & 12 & 3.2 & 8.8 & 13.9 & 7.3 & 1.12 & 0.26 & $4.36 \mathrm{~b}$ & $49.5 \mathrm{~b}$ \\
\hline $\mathrm{CS}$ & 12 & 5.2 & 6.8 & 11.8 & 5.2 & 1.06 & 0.20 & $0.20 \mathrm{~d}$ & $2.9 \mathrm{~d}$ \\
\hline \multicolumn{10}{|l|}{ Clay } \\
\hline Control & & & & 4.8 & & 0.73 & & & \\
\hline SCM & 12 & 2.3 & 9.7 & 6.6 & 1.8 & 0.83 & 0.10 & $-0.40 \mathrm{~d}$ & $-4.2 \mathrm{~d}$ \\
\hline PM & 12 & 3.2 & 8.8 & 11.6 & 6.8 & 0.79 & 0.06 & $3.66 \mathrm{~b}$ & $41.6 \mathrm{~b}$ \\
\hline $\mathrm{CS}$ & 12 & 5.2 & 6.8 & 8.2 & 3.4 & 0.73 & 0.00 & $-1.80 \mathrm{e}$ & $-26.5 \mathrm{e}$ \\
\hline \multicolumn{10}{|l|}{ Peat } \\
\hline Control & 0 & & & 17.3 & & 5.05 & & & \\
\hline $\mathrm{SCM}$ & 12 & 2.3 & 9.7 & 23.3 & 6.0 & 5.08 & 0.03 & $3.73 \mathrm{~b}$ & $38.5 \mathrm{bc}$ \\
\hline PM & 12 & 3.2 & 8.8 & 26.9 & 9.6 & 6.58 & 1.53 & $7.93 \mathrm{a}$ & $90.1 \mathrm{a}$ \\
\hline $\mathrm{CS}$ & 12 & 5.2 & 6.8 & 24.1 & 6.8 & 5.26 & 0.21 & $1.81 \mathrm{c}$ & $26.6 \mathrm{c}$ \\
\hline \multicolumn{10}{|c|}{ Statistical analysis (P-values) } \\
\hline $\mathrm{MT}^{\mathrm{c}}$ & N/A & N/A & N/A & $<0.001$ & $<0.001$ & 0.016 & 0.012 & $<0.001$ & $<0.001$ \\
\hline $\mathrm{ST}^{\mathrm{d}}$ & N/A & $\mathrm{N} / \mathrm{A}$ & N/A & $<0.001$ & $<0.001$ & $<0.001$ & 0.012 & $<0.001$ & $<0.001$ \\
\hline $\mathrm{MT} \times \mathrm{ST}$ & N/A & N/A & N/A & 0.003 & 0.008 & 0.023 & 0.005 & 0.017 & 0.021 \\
\hline
\end{tabular}

${ }^{\mathrm{a}}$ [(N uptake from manure+final mineral $\mathrm{N}$ from manure in the soil $)$ - mineral $\mathrm{N}$ applied with manure]

${ }^{\mathrm{b}}[(\mathrm{A} /$ applied organic manure $\mathrm{N}) * 100]$

${ }^{\mathrm{c}}$ Manure type, ${ }^{\mathrm{d}}$ Soil type, $N / A$ Not applicable

*Values followed by different letters within a column are significantly different $(P<0.05)$ from each other 
Fig. 2 Relationships between a total $\mathrm{N}$ uptake and total DM yield, b shoot $\mathrm{N}$ uptake and shoot DM yield, and $\mathbf{c} \operatorname{root} \mathrm{N}$ uptake and root DM yield of ryegrass. Symbols represent the observed average values of herbage DM yield from control and manured pots, whereas the continuous lines are the trend lines. Error bars depict standard error $( \pm)$ of the mean
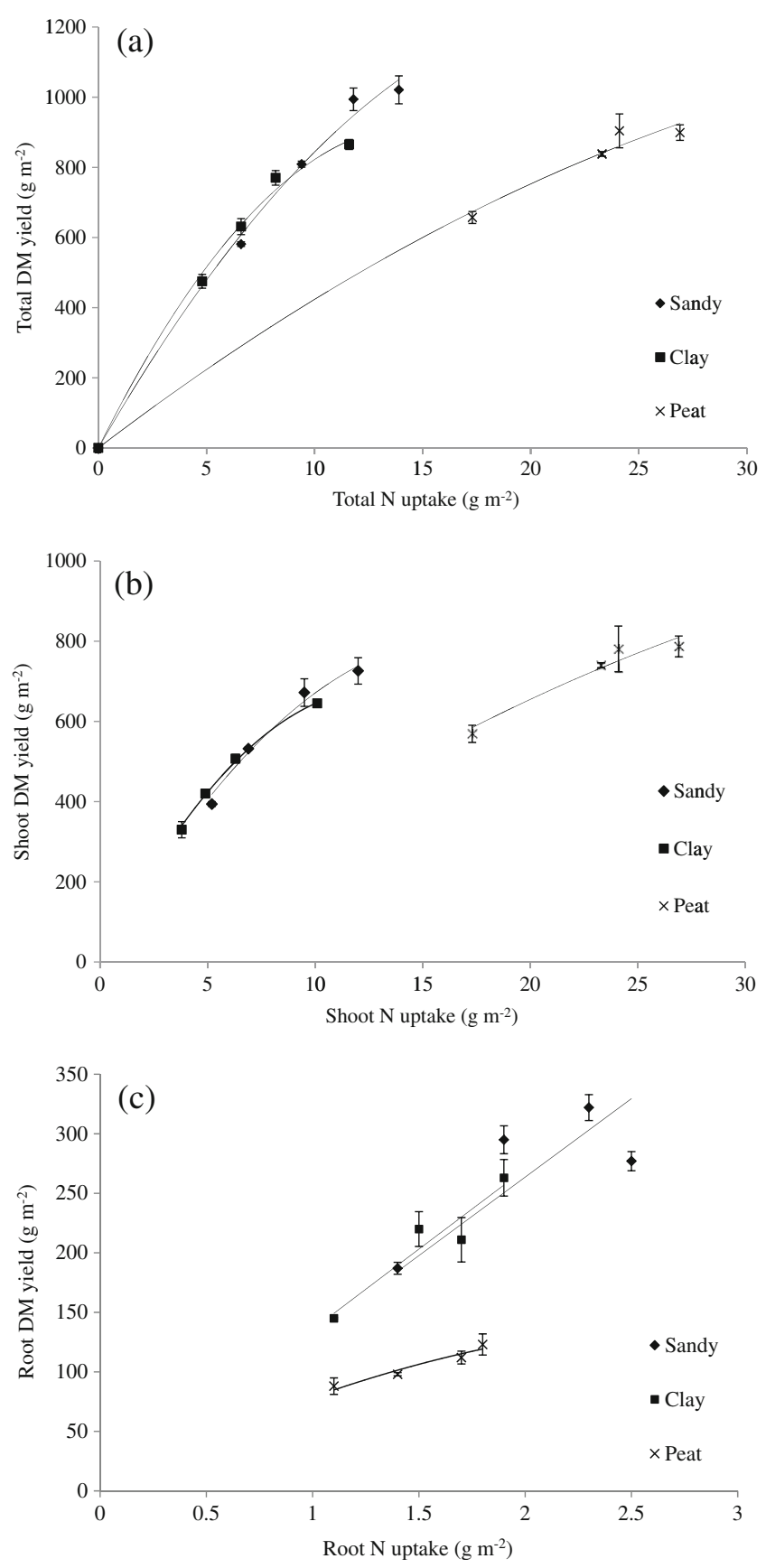

were very clear. For each manure type, the values obtained for all these parameters were highest in the peat soil (Tables $3 \& 4$ and Fig. 1). In addition, plant $\mathrm{N}$ uptake from the unfertilized peat soil was also highest (Table 3). These observations concur with those of Magdoff (1978) who concluded that soils with high soil $\mathrm{N}$ mineralization rates do mineralize $\mathrm{N}$ from added manure more rapidly compared to soils with lower inherit $\mathrm{N}$ availability rates. It should be noted that in our experiment the TNR values and net $\mathrm{N}$ mineralization potential of the peat soil could have been stimulated by the long-term ( $>50$ years) high input rates of crop residues, ditch sludge and animal manures on the dairy farm where this soil was collected (Sonneveld and Lantinga 2010). This farming practice has led to a build-up of young soil OM including young organic $\mathrm{N}$ 
and thereby increased the potential for $\mathrm{N}$ mineralization (Wood and Edwards 1992; Liu et al. 2006).

Regarding the sandy and clay soils, which both had similar $\mathrm{N}$ delivering capacities (Table 3 ), net $\mathrm{N}$ immobilization and lower TNR were observed from SCM and CS in the latter soil type (Table 4 and Fig. 1). This could be attributed in all probability to its higher clay content (Table 1) and not to its higher CEC value, since through the extraction with $\mathrm{CaCl}_{2}$ all $\mathrm{NH}_{4}{ }^{+}$from the cation exchange sites were removed (Stevenson 1982). For this reason, CEC could not have affected the calculated $\mathrm{N}$ balance (Table 4). At high clay contents, fixation of $\mathrm{NH}_{4}{ }^{+}-\mathrm{N}$ in the interlayers of clay minerals will be enhanced (Nommik and Vahtras 1982; Nieder et al. 2011) and microbial immobilization of $\mathrm{NH}_{4}{ }^{+}-\mathrm{N}$ will be stimulated (Sørensen and Jensen 1995b). This is corroborated by Chantigny et al. (2004) who also reported greater fixation of $\mathrm{NH}_{4}{ }^{+}$in clay compared to sandy soil.

Net immobilization of manure $\mathrm{N}$ can be higher in soils with higher soil clay content due to greater protection of the microbial biomass with increasing soil clay content (Amato and Ladd 1992). Therefore, a high amount of $\mathrm{N}$ retained in the microbial biomass is protected from the predators (i.e. nematodes and microarthropods), which in turn results in a lower net $\mathrm{N}$ mineralization rate (Bloem et al. 1997; Laakso et al. 2000). However, this can be affected by the manure characteristics such as water content, which determines the distribution of applied $\mathrm{N}$ in the soil profile and thereby could have an influence on the interactions between manure and soil particles (Sørensen and Jensen 1998). It has previously been shown that the interaction between soil type and cattle slurry $\mathrm{N}$ mineralization is influenced by the distribution pattern of the applied slurry in the soil profile (Sørensen and Jensen 1995a). We suggest that after incorporation of CS and SCM with much higher inherited water contents (Table 2), their soluble compounds were moved deeper into the soil profile through water flow and diffusion, whereas the solid and larger particles remained at the place of application. During this downward transport process $\mathrm{NH}_{4}{ }^{+}-\mathrm{N}$ from the manures could easily be adsorbed on negatively charged surfaces, metabolized $\mathrm{C}$ could be taken up by the micro-organisms and some manure particles could become trapped in the soil matrix and therefore be protected against predation (Petersen et al. 2003). The larger particles of the manures are to be expected to have a high $\mathrm{C} / \mathrm{N}$ ratio because of the presence of straw and thereby may cause immobilization in soil (Whitehead et al. 1989). On the other hand, after application of dry PM (Table 2) water was initially transported from soil into manure particles before decomposition. Therefore, the micro-organisms utilizing $\mathrm{N}$ were remained in the manure clumps and as being unprotected from predators this resulted in increased $\mathrm{N}$ mineralization rates (Sørensen and Jensen 1995a). Our results corroborates with Jingguo and Bakken (1989) as well as Sørensen and Jensen (1995a) who reported that in a heterogeneous soil-plant system with $\mathrm{N}$ mineralizing and immobilizing zones, overall net mineralization and plant uptake of $\mathrm{N}$ can be much higher compared to a similar homogenized system.

On each soil type both net $\mathrm{N}$ mineralization and TNR were highest in the PM treatments. This can be related to the diverging chemical characteristics of the three manure types. The contents of mineral $\mathrm{N}$ compounds ranged from low $\left(19 \%\right.$ of the $\left.\mathrm{N}_{\text {total }}\right)$ in SCM to a much higher fraction in CS (44\%), while PM had an intermediate value (27\%). However, the $\mathrm{N}$ fertilizer value of manure is the sum of its mineral $\mathrm{N}$ content and the mineralizeable organic $\mathrm{N}$ forms. Therefore, the observed higher net $\mathrm{N}$ mineralization and TNR from PM could be attributed to the presence of more readily mineralizeable organic $\mathrm{N}$ compounds (Preusch et al. 2002). According to Tyson and Cabrera (2008), PM contains for the greater part easily degradable $\mathrm{N}$ compounds, i.e. uric acid, which can represent in the order of $70 \%$ of the total $\mathrm{N}$ and therefore readily mineralize after soil application. On the other hand, both in CS and SCM the organic N is more strongly bound and therefore less likely to be released quickly (Chadwick et al. 2000). This was clearly reflected in the constructed $\mathrm{N}$ balance which showed highest net gain of mineral $\mathrm{N}$ through mineralization from PM (Table 4). Compared to our study, somewhat higher values of mineralized $\mathrm{N}$ from $\mathrm{PM}$ and similar values from SCM and CS were found by Chadwick et al. (2000) in a pot experiment with sandy soil for 199 days.

Of the total $\mathrm{N}$ recovered by the grass plants, its distribution between roots and shoots differed greatly among the manure and soil types. In general, a relatively higher proportion of the absorbed $\mathrm{N}$ as well as the produced $\mathrm{DM}$ was allocated to the belowground organs in the treatments with lower amounts of plant available soil $\mathrm{N}$ (Table 3). This can be explained using the functional equilibrium concept. According to this approach DM and $\mathrm{N}$ distribution between root and shoot is regulated by an equilibrium between root and shoot activity (Marcelis et al. 1998). In N-limited conditions root 
activity decreases and plants tend to invest more in root growth in order to explore a large volume of soil for $\mathrm{N}$ to compensate for this. Consequently, root DM and $\mathrm{N}$ yields will increase (Wilson 1988) like in our clay and sandy treatments next to the control. Among the manure types, both these parameters were lowest in case of PM as a result of its high $\mathrm{N}$ mineralization rate (Table 4). These findings are also consistent with observations of Gislum and Griffith (2004) who reported relatively lower root $\mathrm{N}$ yields at increasing contents of plant available soil $\mathrm{N}$.

Interestingly, the total (shoots+roots) DM yield per $\mathrm{kg} \mathrm{N}$ uptake was much lower in the peat soil compared to the other two soils as reflected in the calculated NUE (nitrogen use efficiency) values (Table 3 and Figs. $2 \mathrm{~b}$ and c). According to Simon and Lemaire (1987) DM allocation to shoots increases at high $\mathrm{N}$ availability resulting in higher rates of leaf expansion and elongation. Consequently, the leaf area index (LAI) will increase faster leading to an earlier onset of self-shading of leaves lower in the canopy. This will lead to an early cessation of appearance of new tillers (Mitchell and Coles 1955; Thomas and Norris 1981). Simon and Lemaire (1987) found that tillering of perennial ryegrass growing outdoors terminates after the LAI has reached a value of about 3 , which corresponded with an almost complete elimination of light at the level of the tiller buds near the soil surface. In a greenhouse, where the radiation level is only in the order of $60 \%$ of that outdoors (Dayan et al. 1986), this threshold LAI will even be lower. This is an artefact of doing experiments indoors and is a plausible explanation for the observed more or less twofold lower tiller density in our peat treatments. This reduced tiller density is a clear indication that the developmental shift from a source to a sink limitation of photosynthesis has started already early during the growth cycles of the grass plants on peat. As a result, the total DM yield from the peat treatments at an even double level of $\mathrm{N}$ uptake still lagged behind those obtained in the sandy pots (Table 3). Sink limitation in plant growth imposes next to leaf photosynthates downregulation (Lantinga et al. 1996; Nebauer et al. 2011) also stimulation of both "wastage" respiration (Amthor 2000) and root exudation of C compounds (Walker et al. 2003).

\section{Conclusions}

This study clearly demonstrated the existence of significant interactions between three animal manure and soil types regarding net manure $\mathrm{N}$ mineralization and total plant $\mathrm{N}$ recovery. Overall, both $\mathrm{N}$ mineralization and total plant $\mathrm{N}$ recovery were highest from poultry manure compared to cattle slurry and solid cattle manure. For each manure type, their values were highest in the peat soil which was characterized by the greatest $\mathrm{N}$ delivering capacity. Between the other two soils with more or less similar $\mathrm{N}$ delivering capacities, net $\mathrm{N}$ mineralization and total plant $\mathrm{N}$ recovery from both solid cattle manure and cattle slurry were lower in the clay soil. This could be associated with its inherited higher clay content leading to increased microbial immobilization and fixation of $\mathrm{NH}_{4}^{+}-\mathrm{N}$. The results from this experiment indicate the need for more soil-specific manure fertilizer recommendations and might be used as a first step to re-define and evaluate manure $\mathrm{N}$ mineralization guidelines and models for the above soil types.

Acknowledgments The funding of this study provided by the Higher Education Commission of Pakistan is gratefully acknowledged. We are equally indebted to Wageningen University for providing technical support. Special thanks are due to Hennie Halm for providing assistance in laboratory work and Johannes Scholberg for critically reading the manuscript.

Open Access This article is distributed under the terms of the Creative Commons Attribution License which permits any use, distribution, and reproduction in any medium, provided the original author(s) and the source are credited.

\section{References}

Amato M, Ladd JN (1992) Decomposition of ${ }^{14} \mathrm{C}$-labelled glucose and legume material in soils: properties influencing the accumulation of organic residue $\mathrm{C}$ and microbial biomass C. Soil Biol Biochem 24:455-464

Amthor JS (2000) The McCree-de Wit-Penning de VriesThornley respiration paragigms: 30 years later. Ann Bot $86: 1-20$

Anonymous (1998) NEN 7432 Manure and derivatives. Determination of the contents of dry matter and organic matter (in Dutch). Gravimetric method. Dutch Standardization Institute (NNI), Delft

Bais HP, Weir TL, Perry LG, Gilroy S, Vivanco JM (2006) The role of root exudates in rhizosphere interactions with plants and other organisms. Annu Rev Plant Biol 57:233-266

Bengtsson G, Bengtson P, Mansson KF (2002) Gross nitrogen mineralization-, immobilization-, and nitrification rates as a function of soil $\mathrm{C} / \mathrm{N}$ ratio and microbial activity. Soil Biol Biochem 35:143-154

Bloem JD, Ruiter P, Bouwman L (1997) Soil food webs and nutrient cycling in agroecosystems. In: van Elsas DJ, Trevors TJ, Wellington HME (eds) Modern soil microbiology. Marcel Dekker, Inc. New York, pp 245-275 
Brockman JS (1988) Crop nutrition. In: Halley RJ, Soffe RJ (ed) The agriculture note book, 18th edn. London, pp 70-89

Buurman P, Pape T, Reijnveld JA, de Jong F, van Gelder E (2001) Laser-diffraction and pipette-method grain sizing of Dutch sediments: correlations for fine fractions of marine, fluvial, and loess samples. Ned J Geo Sci 80:49-57

Castellanos JZ, Pratt PF (1981) Mineralization of manure nitrogen-correlation with laboratory indexes. Soil Sci Soc Am J 45:354-357

Chadwick DR, John F, Pain BF, Chambers BJ, Williams J (2000) Plant uptake of nitrogen from the organic nitrogen fraction of animal manures: a laboratory experiment. J Agric Sci 134:159-168

Chae YM, Tabatabai MA (1986) Mineralization of nitrogen in soils amended with organic wastes. J Environ Qual 15:193-198

Chantigny MH, Angers DA, Morvan T, Pomar C (2004) Dynamics of pig slurry nitrogen in soil and plant as determined with N-15. Soil Sci Soc Am J 68:637-643

Chescheir GM, Westermann PW, Safley LM (1986) Laboratory methods for estimating available nitrogen in manures and sludges. Agr Wastes 18:175-195

Dayan E, Enoch HZ, Fuchs M, Zipori I (1986) Suitability of greenhouse building types and roof cover materials for growth of export tomatoes in the besor region of Israel. I. Effect on climatic conditions. Biotron 15:61-70

Gislum R, Griffith SM (2004) Tiller production and development in perennial ryegrass in relation to nitrogen use. $\mathrm{J}$ Plant Nutr 27:2135-2148

Hodge A, Stewart J, Robinson D, Griffiths BS, Fitter AH (2000) Competition between roots and soil micro- organisms for nutrients from nitrogen-rich patches of varying complexity. J Ecol 88:150-164

Houba VJG, Van Der Lee JJ, Novozamsky I, Walinga I (1989) Soil and plant analysis, a series of syllabi, Part 5. Wageningen University, the Netherlands

Jingguo W, Bakken LR (1989) Nitrogen mineralization in rhizosphere and non-rhizosphere soil, effect of the spatial distribution of N-rich and N-poor plant residues. In: Hansen JA, Henriksen K (eds) Nitrogen in organic wastes supplied to soils. Academic, London, pp 81-97

Jonasson S, Castro J, Michelsen A (2006) Interactions between plants, litter and microbes in cycling of nitrogen and phosphorus in the arctic. Soil Biol Biochem 38:526-532

Katterer T, Reichstein M, Anren O, Lomander A (1998) Temperature dependence of organic matter decomposition: a critical review using literature data analyzed with different models. Biol Fertil Soils 27:258-262

Laakso J, Setälä H, Palojärvi J (2000) Influence of decomposer food web structure and nitrogen availability on plant growth. Plant Soil 225:153-165

Lantinga EA, Gaborcik N, Dirks BOM (1996) Ecophysiological aspects of herbage production in grazed and cut grassland. In: Parente G, Frame J, Orsi S (ed) Grassland and land use systems. Proceedings of the $16^{\text {th }}$ general meeting of the European grassland federation Italy, pp 151-161

Liu X, Herbert SJ, Hashemi AM, Zhang X, Ding G (2006) Effects of agricultural management on soil organic matter and carbon transformation-a review. Plant Soil Environ 52:531-543
MAFF (1979) Profitable utilization of livestock manures. ADAS Booklet 2081, HMSO, London

MAFF (1986) The analysis of agricultural materials. Ministry of agriculture fisheries and food, reference Book 427. HMSO, London

Magdoff FR (1978) Influence of manure application rates and continuous corn on soil-N. Agron J 70:629-632

Marcelis LFM, Heuvelink E, Goudriaan J (1998) Modelling biomass production and yield of horticultural crops: a review. Scientia Horti 74:83-111

Mitchell KJ, Coles STJ (1955) Effects of defoliation and shading on short rotation rye-grass. N Z J Sci Tech 36:586-604

Mosier AR, Doran JW, Freney JR (2002) Managing soil denitrification. J Soil Water Conserv 57:505-513

Nebauer SG, Renau-Morata B, Gurdiola JL, Molina RV (2011) Photosynthesis down-regulation preceeds carbohydrate accumulation under sink limitation in Citrus. Tree Physiol 31:169-177

Nieder R, Benbi DK, Scherer HW (2011) Fixation and defixation of ammonium in soils: a review. Biol Fertil Soils 47:1-14

Nommik H, Vahtras K (1982) Retention and fixation of ammonium and ammonia in soils. In: Stevenson FJ (ed) Nitrogen in agricultural soils. Agronomy 22, American Society of Agronomy, Madison, pp 123-171

Petersen SO, Nissen HH, Lund I, Ambus P (2003) Redistribution of slurry components as influenced by injection method, soil and slurry properties. J Environ Qual 32:2399-2409

Preusch PL, Alder PR, Sikora LJ, Tworkoski TJ (2002) Nitrogen and phosphorus availability in composted and uncomposted poultry manure. J Environ Qual 31:2051-2057

Schjonning P, Thomsen IK, Moberg JP, de Jonge J, Kristensen K, Christensen BT (1999) Turnover of organic matter in differently textured soils, I: physical characteristics of structurally disturbed and intact soils. Geoderma 80:177-198

Sharkey MJ (1970) Errors in measuring nitrogen and dry matter content of plant and faeces material. J Brit Grassl Soc 25:289-294

Simon JC, Lemaire G (1987) Tillering and leaf area index in grasses in the vegetative phase. Grass Forage Sci 42:373380

Sonneveld MPW, Lantinga EA (2010) The contribution of mineralization to grassland $\mathrm{N}$ uptake on peatland soils with anthropogenic A horizons. Plant Soil 340:357-368

Sørensen P, Jensen ES (1995a) Mineralization-immobilizing and plant uptake of nitrogen as influenced by the spatial distribution of cattle slurry in soils of different texture. Plant Soil 173:283-291

Sørensen P, Jensen ES (1995b) Mineralization of carbon and nitrogen from fresh and anaerobically stored sheep manure in soils of different texture. Biol Fert Soils 19:29-35

Sørensen P, Jensen ES (1998) The use of ${ }^{15} \mathrm{~N}$ labelling to study the turnover and utilization of ruminant manure N. Biol Fertil Soils 28:56-63

Stevenson FJ (1982) Nitrogen in agricultural soils. Agronomy 22, American Society of Agronomy, Madison

Thomas H, Norris JB (1981) The influence of light and temperature during winter on growth and death in simulated swards of Lolium perenne. Grass Forage Sci 36:107-116 
Thomsen IK, Olesen JE (2000) C and N mineralization of composted and anaerobically stored ruminant manure in differently textured soils. J Agric Sci Cambr 135:151-159

Tyson SC, Cabrera ML (2008) Nitrogen mineralization in soils amended with composted and non-composted poultry litter. Comm Soil Sci Plant Anal 24:2361-2374

Van Veen JA, Kuikman PJ (1990) Soil structure aspects of decomposition of organic matter by micro-organisms. Biogeochemistry 11:213-233

Walker TS, Bais HP, Grotewold E, Vivanco JM (2003) Root exudation and rhizosphere biology. Plant Physiol 132:44-51

Watts DB, Torbert H, Prior SA (2007) Mineralization of nitrogen in soils amended with dairy manure as affected by wetting/drying cycles. Comm Soil Sci Plant Anal 38:2103-2116
Webb J, Pain B, Bittman S, Morgan J (2010) The impacts of manure application methods on emissions of ammonia, nitrous oxides and crop response-A review. Agr Ecosyst Environ 137:39-46

Whitehead DC, Bristow AW, Pain BF (1989) The influence of some cattle and pig slurries on the uptake of nitrogen by ryegrass in relation to fractionation of the slurry N. Plant Soil 117:111-120

Wilson JB (1988) A review of evidence on the control of shoot: root ratio, in relation to models. Ann Bot 61:433-449

Wood CW, Edwards JH (1992) Agroecosystem management effects on soil carbon and nitrogen. Agri Ecosyst Environ 39:123-138

Yang XM, Drury CF, Reynolds WD, Tan CS (2004) Nitrogen mineralization and uptake by ryegrass in a clay loam soil amended with composts or liquid pig manure. Can J Soil Sci 84:11-17 